\title{
Adopting Broadcast Media Sensitization Campaigns for Solid Waste Management
}

\author{
Akpoghiran I Patrick ${ }^{1 *}$ and Okoro Ferdinard ${ }^{2}$ \\ ${ }^{1}$ Department of Mass Communication, Western Delta University, Oghara, Delta State, Nigeria \\ ${ }^{2}$ Department of Communication, Delta State Polytechnic, Otefe-Oghara, Nigeria
}

\begin{abstract}
Attitude can be associated as one of the fundamental problems with solid waste management. Poor public attitudes of improper waste disposal as well as lack of self-consciousness of a clean environment constitute one of the greatest problems of solid waste management in Nigeria. Broadcast media can help to influence people's attitudes. Heavy dependency and exposure to the media tend to shape people's beliefs, attitudes and perceptions about solid waste management. This study examines media sensitization campaigns for solid waste management in two cities and states in Nigeria. Using the instrument of questionnaire to elicit data from respondents, the study showed that the broadcast media have carried out sensitization campaigns on solid waste management, but the extent and inhabitants' attitudes towards solid waste management were poor. It is recommendable to have regular but aggressive sensitization campaigns on solid waste management by the broadcast media, which as a matter of importance, should be concerned of all stakeholders in environmental management.
\end{abstract}

Keywords: Attitude; Broadcast media; Campaigns; Sensitization; Solid waste management

\section{Introduction}

The existing solid waste management system in Nigeria is very rudimentary, inefficient and unsustainable. Accurate data on the quantities of municipal solid waste generated are not easy to come by [1]. Proper dump sites and containers are not adequately provided by the appropriate authorities. Even when provided, poor public attitudes of improper waste disposal and utilisation of waste containers as well as lack of self-consciousness of a clean environment constitute one of the greatest challenges of solid waste management in Nigeria.

Attitude has been associated as one of the fundamental problems with solid waste management [2,3]. Earlier, environmental problems were considered as technical and economic problems; while in the recent decades the social dimensions of environmental problems such as public attention and people's attitudes towards environment have become one of the areas of environmental sociology and environmental psychology [4]. Actually, the management of household refuse, according to Navez-Bounchaire cited in Banjo, Adebambo and Dairo [5], is tied to perceptions and socio-cultural beliefs and practices. Navez-Bounchaire observed that, in cultural beliefs, most people think that sanity belongs to women, and this is why communication through the broadcast media is imperative to change people's beliefs and attitudes. Communication through the broadcast media is capable of raising public awareness, perceptions and attitudes to solid waste management. Olgyaiová, Pongrácz, Mikkola, Škapa and Keiski [6] argued that the lack of environmental awareness is a major problem in our society. By this, they believe that knowledge has to be supported by will, information and abilities to behave in an environmentally friendly way. They suggested that awareness should be created among residents to manage household refuse and educate them on the hazards that illdisposed waste could pose to the environment and to inhabitants.

Complement to the above, communication becomes necessary to create public enlightenment or awareness and education on waste management. Mass enlightenment through the broadcast media for example, can help to influence and persuade people to change their beliefs, promotes their values and attitudes towards solid waste. This forms the essence of the study.

\section{Objectives of the Study}

In a broader perspective, this study is to expand the scope of knowledge on solid waste management by looking at it from the angle of enlightenment campaigns by the broadcast media. The study specifically seeks, among other things to:

- To determine respondents' level of awareness on solid waste management through the broadcast media sensitizations.

- To ascertain whether inhabitants' methods of solid waste management depend on broadcast media sensitizations.

- Many studies have focused on solid waste compositions, sources, generation and related themes, this study focuses on effective environmental management or responsible environmental behaviour through behaviour change communication (BCC).

\section{Literature Review}

Studies have shown that communication has helped to promote environmental behaviour. Rim-Rukeh and Ogbemi $[7,8]$ believe that "communication can help individuals to understand the interaction between resources (natural) and the environment". Barr [9] had observed greater knowledge of environmental principles, attitudes and theories of waste reduction through communication to enhance individual's ability to participate in solid waste management. It is on this premise that Nwodu [10] defines environmental communication as a "conscious communicative effort to bring people to the knowledge

*Corresponding author: Akpoghiran I Patrick, Department of Mass Communication, Western Delta University, Oghara, Delta State, Nigeria, Tel: +2348037794099; E-mail: patre216@yahoo.co.uk

Received February 04, 2014; Accepted July 25, 2014; Published August 01, 2014

Citation: Patrick Al, Ferdinard O (2014) Adopting Broadcast Media Sensitization Campaigns for Solid Waste Management. J Mass Communicat Journalism 4: 208 doi:10.4172/2165-7912.1000208

Copyright: (C) 2014 Patrick Al, et al. This is an open-access article distributed under the terms of the Creative Commons Attribution License, which permits unrestricted use, distribution, and reproduction in any medium, provided the original author and source are credited. 
of environmental problems around them; encourage them to desist from actions that are harmful to the environment and sensitise them to show greater commitment to activities aimed at safeguarding the environment" [10]. Nwabueze [10] notes that communication is an integral part of environmental management because it is central to every human activity and as such, would be used in coordinating the resources for a 'synergistic' approach to management of the environment. Therefore, environment communication consists of all forms of communications to keep the public enlightened about and aware of environmental issues and trends. It is based on this reason that the role of communication in solid waste management becomes imperative. These roles, as highlighted by Rim Rukeh and Ogbemi $[7,8]$ are to raise awareness in environmental issues and it can be used to promote responsible environmental behaviour, especially for solid waste management. In addition, it enables government and its agencies to know areas where solid waste management needs serious and urgent attention. In the same vein, Macawile and Sia Su [3] believe that a conscious effort through communication is needed to incorporate the interests of both the community leaders and the public in understanding their roles, relationships and contributions through their perceptions and attitudes as all are recognized as important stakeholders in attaining a sustainable environmentally oriented effort. In essence, communication is one of the vital ways by which people in any given environment could relate. The essence of environment which deals with living together of all organisms in the environment is only possible and realisable through the use of communication. As a matter of fact, "communication is a fundamental process of socialisation of people in any given environment" [10].

Communication can therefore be used to influence people's dispositions for a friendly environment. Although, mass communication messages may not change existing deep rooted attitudes but may rather influence it. The ultimate goal is to activate public efforts towards behavioural change in environmental management.

Environmental campaigns could be pursued using different media like radio and television. Radio, for example, is believed to be the most effective, popular and credible medium for reaching a large and heterogeneous audience. It is relatively cheap, available and accessible. It can be powered by battery, requiring insignificant literacy level to comprehend. Radio remains the most potent and effective environmental communication tool for reaching a vast range of audience in developing nations like Nigeria [10]. In the same development, television is believed to make the most impact on the audience. This is because of its audio-visual advantage. It leaves a lasting impression in the minds of the audience. Television can reach diverse people simultaneously and provide opportunity for a message to be demonstrated in images or pictures. In a study of inhabitants' perception on domestic waste disposal in Ijebu Ode, Southwest Nigeria, Banjo, Adebambo and Dairo [5] result showed that radio and television were the most available (93\% and $96 \%$ respectively), the most easily accessed (70\% and 73\% respectively) and the most effective sources of environmental information ( $61 \%$ and $64 \%$ respectively). Their study showed the effectiveness of the mass media, particularly the radio and television in creating awareness about public health and environmental issues. Radio and television are often associated with their wide geographical coverage and the relatively cheap cost of acquiring and using them in contrast to the print media [5]. Both media (radio and television) are effective environmental communication tools which could be used to raise public awareness and consciousness towards environmental concerns with a high degree of effectiveness. Broadcast media enlightenment campaigns on solid waste management can come in any form of: radio jingles, television commercials (green advertising), main news bulletin, public service announcement, health programmes and so on.

It is instructive to know that the degree to which the broadcast media devote air time to environmental news also affect people's attitudes towards the environment. As it were, heavy dependency and exposure to the media tend to shape people's beliefs and perceptions about various issues of life. Aptly put, the degree of dependency on the media is a key variable that help to explain why audience's beliefs, feelings or behaviours are altered. In this wise, environmental news is a potent force for responsible environmental behaviour. Individual exposure to a greater amount of environmental news is more likely to show concern with environmental management.

\section{Materials and Method}

Both primary and secondary sources of materials were used for the study. Books and journals on the subject matter were consulted and views were elicited from the respondents through the instrumentality of the questionnaire.

\section{Population and sampling design}

The scope of the study was limited to Edo and Delta in the southsouth geo-political zone of Nigeria. Only cities with highest population of residents in these states were chosen. The reason was that these cities have the largest population, and perhaps, solid waste generation and management. And in addition, there are broadcast media stations in these cities. They were Benin City in Edo state and Warri metropolis in Delta state. As at 2006 National Census Population, the population of Benin City was 374,515 and that of Warri metropolis, was 311,970 (www.population.gov.ng and www.nigerianstat.gov.ng). The total population is 686,485 .

There are various broadcast media stations in these two cities. These are but not limited to the following: In Benin city, we have, Independent Radio and Television; Silverbird Rhythm FM; Vibes FM; Bronze FM (of FRCN); Raypower FM; Edo Broadcasting Service (EBS) and Nigerian Television Service. In Warri, we have, Delta Broadcasting Service (DBS); Crown FM and JFM. In total, there are nine (9) broadcast media stations in these two cities.

\section{Sample size}

In determining the sample size for this study, the Australian Calculator as provided by the National Statistical Service (NSS) was employed. The sample size calculator allows the researcher to calculate the required responding sample size, standard error, RSE, and a confidence interval ( $95 \%$ or $99 \%$ ) for a proportion estimate, using just one of these criteria as an input. The estimated variance proportion was $0.5(5 \%)$, the confidence interval was set at $0.05(5 \%)$ and the total population from these two cities was 686,485 (Figure 1).

By this calculation, 385 becomes the basic sample size. To calculate for the oversampling procedure as a result of the large population, a response rate estimate of $40 \%$ was adopted. The calculation is presented:

Minimum sample size

$\mathrm{n}_{2}=$ Anticipated response rate

Where anticipated return rate $=40 \%(0.40)$

Where $\mathrm{n}_{2}=$ sample size adjusted for response rate.

Where minimum sample size $=385$ 


\begin{tabular}{|c|c|c|c|}
\hline & Confidence Level: & $95 \% \quad-$ & i \\
\hline & Population Size: & 686,485 & i. \\
\hline & Proportion: & 0.5 & i \\
\hline 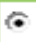 & Confidence Interval: & 0.05 & i \\
\hline & Upper & 0.55000 & \\
\hline & Lower & 0.45000 & \\
\hline$c$ & Standard Error & 0.02551 & i \\
\hline c & $\begin{array}{l}\text { Relative } \\
\text { Error }\end{array}$ & 5.10 & i \\
\hline$c$ & Sample Size & 385 & i \\
\hline
\end{tabular}

Figure 1: The Australian Calculator.

Therefore:

Minimum sample size is 385

$\mathrm{n}_{2}=$ Anticipated response rate is $40 \%$

$\mathrm{n}_{2}=385 / 0.40=963$

The sample size for the survey aspect of study was 963 respondents

However, to determine the distribution of the questionnaire according to the population sizes, the working was thus:

Population of a city $\times$ sample size

Total population of all the two cities

Benin City in Edo state: $\underline{374,515} \times 963=525$

686,485

Warri in Delta state: $\underline{311,970 \times 963}=438$

686,485

Total $=963$

The working showed how the copies of the questionnaire were administered.

The reliability and validity of the instrument was measured through a test and re-test approach. A pre-test questionnaire of 20 copies were designed and administered to postgraduate students of the University of Nigeria, Nsukka (UNN) with the aid of a research assistant. After four weeks interval, the same pre-test copies of questionnaire were administrated to the same respondents where some errors and observations were made. The essence was to elicit observations, views and perhaps criticisms about the questionnaire before being administered to the public. The Guttman scale of coefficient of reproducibility was adopted to measure the reliability of the instrument. A total of 2 errors were observed. The working was:

Total error/1-Total responses

$2 / 1-20$

$2 / 20=0.10$

$1-0.10=0.90(90 \%)$

The instrument yielded reliability coefficient value of $90 \%$, an indication of internal consistency and validity. Simple percentages and mean were used to analyze the data collected.

\section{Measuring scale}

Respondents' awareness and attitude on environmental behaviour were measured through the administration of questionnaire. The purposive sampling technique was adopted. The places purposively targeted were: residential homes; market places; shopping malls; school hostels; business centres and shops. The technique employed to analyse the obtained data was descriptive statistics of frequency count, percentage, mean and chi-square to test the hypotheses. Responses to the questionnaire were pooled, edited and scored. Nominal values were assigned to the items according to scales. For example, in (Table 1 ), questions on general knowledge on solid waste had an assigned score of 5-1. The options provided in this table were based on the question asked. Mean $(X)$ was used to analyse the data in this table. To determine the mean point for table, the working was total number of the ranking of $5-1$ scale $(5+4+3+2+1=15)$ divided by (no. of scale or options $=5$ ). For example, we have $15 \div 5=3.0$. In this way, 3.0 becomes the midpoint or benchmark/mean value for all items in the table. Therefore, any item whose response is greater than 3.00 is accepted but lesser than 3.00 is rejected or $(\bar{X}>3.00$ and $\bar{X}<3.00)$. (Tables 2 and 3 ) adopted the 'Yes or No' option. Percentages were used to analyse the data. Table 4 determines respondent's specific behaviour towards solid waste management. The Likert scale of strongly agree; agree; undecided; disagree and strongly disagree was adopted.

\section{Results}

The sample returned ( $\mathrm{n}-959)$, representing $99.5 \%$ of the sample size, consisted of 258 (27\%) males and 701 (73\%) females. The ages between 18-24 consisted of 167 (17.4\%) respondents, those between 25 -34 ages were $176(18.3 \%), 35-45$ ages were $399(41.6 \%)$ and those between 45 -above were $217(22.6 \%)$ respondents respectively. On marital status, there were 323 singles respondents representing (33.6\%), 405 married respondents representing $(42.2 \%)$ and 231 of the respondents were widows $(24.1 \%)$. There were 348 (36.3\%) respondents who had secondary education and 611 (63.7\%) with higher education. Also, there were $130(13.5 \%)$ students, 301 (31.3\%) traders, $299(31.1 \%)$ public servants, 141 (14.7\%) were businessmen and women while 33 (3.4\%) lecturers. There were also 55 (5.7\%) health workers such as medical practitioners and nurses.

Using the Ho hypothesis that public' level of awareness on solid waste management do not depend on broadcast media campaigns, the result showed that since $(.000<0.05)$, the $\mathrm{Hi}$ was rejected, it is therefore concluded that respondents' level of awareness on solid waste management do not depend on broadcast media sensitizations (Figures 2-4).

Using the Ho hypothesis that inhabitants' awareness and attitude to solid waste management do not depend on broadcast media campaigns, 


\begin{tabular}{|c|c|c|c|c|c|c|}
\hline faltems & $\begin{array}{l}\text { Agree } \\
(5)\end{array}$ & $\begin{array}{l}\text { Fairly agree } \\
\text { (4) }\end{array}$ & $\begin{array}{l}\text { Undecided } \\
\text { (3) }\end{array}$ & $\begin{array}{l}\text { Disagree } \\
\quad(2)\end{array}$ & $\begin{array}{c}\text { Fairly } \\
\text { disagree } \\
\text { (1) }\end{array}$ & $\bar{X}$ \\
\hline The broadcast media in this state carry out reports on solid waste problems? & 200 & 159 & 250 & 170 & 182 & 3.32 \\
\hline $\begin{array}{l}\text { There have been regular enlightenment campaigns on solid waste } \\
\text { management by the broadcast media? }\end{array}$ & 190 & 110 & 300 & 179 & 178 & 2.94 \\
\hline $\begin{array}{l}\text { You have been influenced to do more on solid waste management in your } \\
\text { area as a result of broadcast media sensitizations? }\end{array}$ & 170 & 130 & 280 & 189 & 190 & 2.89 \\
\hline $\begin{array}{l}\text { The extent of public awareness sensitizations by the broadcast media on solid } \\
\text { waste has been satisfactory? }\end{array}$ & 251 & 199 & 121 & 210 & 180 & 3.14 \\
\hline $\begin{array}{l}\text { Attitudes of inhabitants to solid waste disposal practice in your area have } \\
\text { been positive/good? }\end{array}$ & 91 & 104 & 113 & 352 & 299 & 2.30 \\
\hline Weighted Mean & & & & & & 2.91 \\
\hline
\end{tabular}

Assigned numbers in bracket; Set mean was (3.00), Sample population (n-959) and obtained mean in $(\bar{X})$.

Table 1a: Broadcast media campaigns and public' level of awareness on solid waste.

\begin{tabular}{|l|c|c|c|c|c|}
\hline & Agree & $\begin{array}{c}\text { Fairly } \\
\text { agree }\end{array}$ & Undecided & Disagree & $\begin{array}{c}\text { Fairly } \\
\text { disagree }\end{array}$ \\
\hline Chi-Square & $75.173^{\mathrm{a}}$ & $75.173^{\mathrm{a}}$ & $75.173^{\mathrm{a}}$ & $75.173^{\mathrm{a}}$ & $75.173^{\mathrm{a}}$ \\
\hline Df & 4 & 4 & 4 & 4 & 4 \\
\hline Asymp. Sig. & .000 & .000 & .000 & .000 & .000 \\
\hline
\end{tabular}

a: 0 cells $(0.0 \%)$ have expected frequencies less than 5 . The minimum expected cell frequency is 180.4 ; significance level 0.05 ; result .000

Table 1b: Chi- Square results from Table 1a.

\begin{tabular}{|c|c|c|c|}
\hline S. No. & Items & Frequency & Percentage \\
\hline 1 & Through government radio stations. & 138 & $14.4 \%$ \\
\hline 2 & Through private radio stations. & 299 & $31.2 \%$ \\
\hline 3 & Government television stations. & 411 & $42.8 \%$ \\
\hline 4 & Private television stations. & 111 & $11.5 \%$ \\
\hline Total & & $\mathbf{9 5 9}$ & $\mathbf{1 0 0} \%$ \\
\hline
\end{tabular}

Table 2: How respondents' received the broadcast media sensitizations on solid waste.

\begin{tabular}{|c|c|c|}
\hline Items & Frequency & Percentage \\
\hline Metal garbage can & 21 & $2.2 \%$ \\
\hline Plastic bag/basket & 409 & $42.6 \%$ \\
\hline Polythene bag & 529 & $55.2 \%$ \\
\hline Total & $\mathbf{9 5 9}$ & $\mathbf{1 0 0} \%$ \\
\hline
\end{tabular}

Table 3a: Respondents' practice towards SWM: kinds of waste container and disposal method.

\begin{tabular}{|l|c|c|}
\hline Items & Frequency & Percentage \\
\hline Burn it? & 47 & $4.9 \%$ \\
\hline Bury it? & 56 & $5.8 \%$ \\
\hline Dump it in the trash can outside the house? & 389 & $40.5 \%$ \\
\hline $\begin{array}{l}\text { Dump it in a secluded spot away from the } \\
\text { neighbourhood? }\end{array}$ & 166 & $17.3 \%$ \\
\hline $\begin{array}{l}\text { Collected and taken to the landfill by paid waste } \\
\text { collectors? }\end{array}$ & 301 & $31.3 \%$ \\
\hline Total & $\mathbf{9 5 9}$ & $\mathbf{1 0 0 \%}$ \\
\hline \multicolumn{2}{|c|}{ Table 3b: Types of waste disposal method. } \\
\hline
\end{tabular}

the result showed that, since $(1.000>0.05$, the $\mathrm{Hi}$ was accepted), it is therefore concluded that inhabitants' awareness and attitude to solid waste management depend on broadcast media campaigns.

\section{Discussion}

Results in item 1 of (Table 1) showed that broadcast media in the two states (Delta \& Edo) under study have carried out reports on solid waste problems (since $3.32>3.00$ ). Whereas, in item 2, at a mean at $(2.94<3.00)$ solid waste management enlightenment campaigns by the broadcast media in those states have not been regular. Irregular sensitizations of the broadcast media on solid waste were evident in item 3 as mean obtained $(2.89<3.00)$ showed that respondents' were not influenced to do more on solid waste management in their areas even with the broadcast media sensitizations. This shows poor enlightenment campaigns by the broadcast media solid waste management. Although, at a mean at $(3.14>3.00)$, the extent of public awareness sensitizations by the broadcast media on solid waste have been satisfactory, however, inhabitants' attitudes to solid waste disposal practice have not been positive/proactive $(2.30<3.00)$ [11]. This also implies poor attitudes to SWM.

In (Table 2), respondents were asked to indicate which medium they received SWM sensitization campaigns most. From the data obtained, many of the respondents $(42.8 \%)$ received SWM sensitization from government television stations (like National Broadcasting Commission) while $31.2 \%$ of the respondents received it through private radio stations (like Maram's GL Heavens).

Further to the above, Table 3 (A and B) centred on personal attitude towards SWM. Respondents were asked to indicate kinds of waste container and disposal method they use. Many of the respondents representing $55.2 \%$ use polythene bags to store their wastes and, as shown in table 3B, $40.5 \%$ of the respondents' dump their waste in trash can outside their house.

At a mean at $(3.13>3.00)$ in item 1 of (Table 4$)$, result showed that the broadcast media have helped in terms of public awareness on SWM. Also, inhabitants' attitude towards SWM depends on broadcast media sensitizations. The result to this was $3.36>3.00$. The above result gives credence to the result in item 3 that right methods to solid waste management depended on broadcast media sensitization campaigns. But right attitude to waste management was a matter of personal beliefs and values not as a result of media sensitizations $(3.10>3.00)$. However, at a mean at $(2.98<3.00)$ issues in global warming and climate change in the media do not affect people's attitude to SWM. The results obtained from the standard deviation showed the divergent views that were expressed by respondents as to the questions asked (Tables 1 and 4).

Going by the result obtained from the chi-square analyses, it was concluded that respondents' level of awareness on solid waste management do not depend on broadcast media sensitizations but rather, inhabitants' attitude to solid waste management depend on broadcast media campaigns. 
Citation: Patrick AI, Ferdinard O (2014) Adopting Broadcast Media Sensitization Campaigns for Solid Waste Management. J Mass Communicat Journalism 4: 208. doi:10.4172/2165-7912.1000208

Page 5 of 6

\begin{tabular}{|c|c|c|c|c|c|}
\hline \multicolumn{6}{|l|}{ Items } \\
\hline \multicolumn{6}{|c|}{ The broadcast media have helped in terms of public awareness on SWM. } \\
\hline \multicolumn{6}{|c|}{ Inhabitants' attitude towards SWM depends on broadcast media sensitizations. } \\
\hline \multicolumn{6}{|c|}{ Right methods to SWM depend on broadcast media sensitizations. } \\
\hline \multicolumn{6}{|c|}{$\begin{array}{l}\text { Right attitude to waste management is a matter of personal beliefs and values not } \\
\text { sensitizations. }\end{array}$} \\
\hline \multicolumn{6}{|c|}{ Issues in global warming and climate change in the media are affecting people's a } \\
\hline \multicolumn{6}{|c|}{ Weighted Mean } \\
\hline \multicolumn{6}{|c|}{ Set mean was (3.00), Sample population (n-959) and obtained mean in $(\bar{X})$} \\
\hline & & & Tabl & nhabita & wareness a \\
\hline & SA & A & UD & D & SD \\
\hline Chi-Square & $.000^{\mathrm{a}}$ & $.000^{\mathrm{a}}$ & $.000^{\mathrm{a}}$ & $.000^{\mathrm{a}}$ & $.000^{\mathrm{a}}$ \\
\hline Df & 4 & 4 & 4 & 4 & 4 \\
\hline Asymp. Sig. & 1.000 & 1.000 & 1.000 & 1.000 & 1.000 \\
\hline
\end{tabular}

a: 5 cells $(100.0 \%)$ have expected frequencies less than 5 . The minimum expected cell frequency is 1.0. significance level 0.05 ; result 1.000

Table 4b: Chi- Square results from table $4 a$

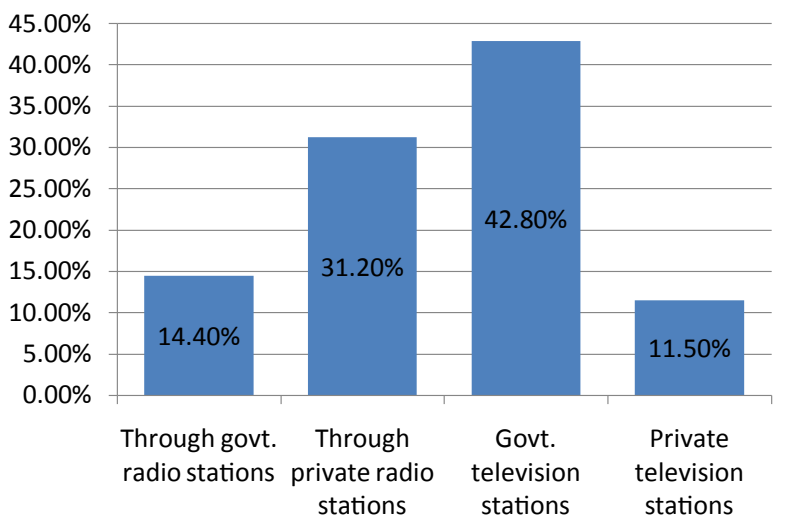

Figure 2: Reception of broadcast media sensitizations on solid waste illustrated in chart.

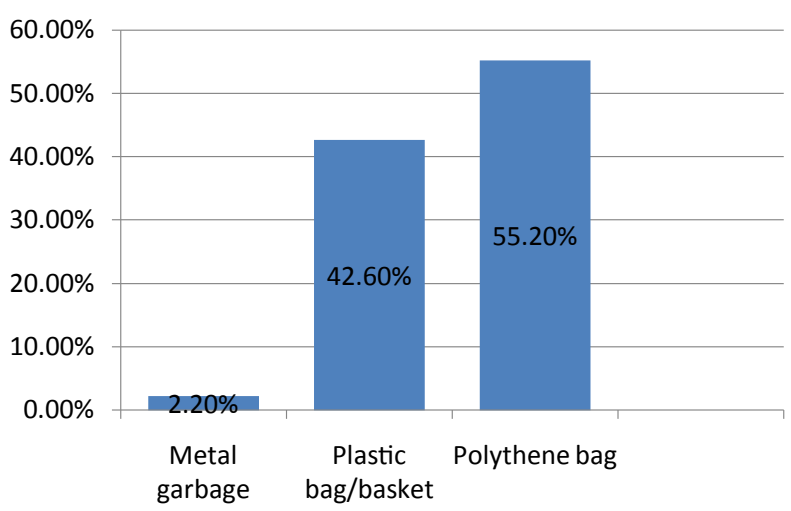

Figure 3: Kinds of waste container illustrated in chart.

\section{Conclusion and Recommendations}

In all, the broadcast media have not done enough in terms of sensitization of inhabitants towards positive attitudes on solid waste management. Many cities in Nigeria are presently fighting a battle

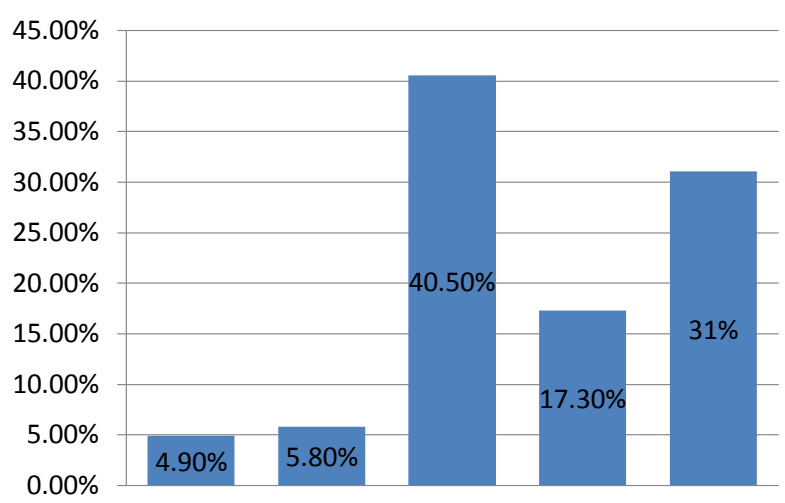

Figure 4: Waste disposal method illustrated in chart.

against municipal solid waste. Management of waste in Nigerian cities continues to pose serious challenges due to the absence of appropriate and organised waste management culture. The broadcast media are awakening public interest on environmental issues. Their roles in public enlightenment on solid waste management are important; however, solid waste management enlightenment campaigns by the broadcast media for public behaviour change is minimal. This is as because campaigns on waste management are not consistent and persistent. The import of poor sensitization campaigns on solid waste management is poor inhabitants' attitude.

It is recommendable to have regular but aggressive sensitization campaigns on solid waste management by the broadcast media, which as a matter of importance, should be concerned of all stakeholders in environmental management. There is need for conferences and seminars on environmental matters by the government, university and NGO's; organized collection of waste by private firm that contracted by the government; environmental education at the secondary school level; and strict enforcement of environmental laws and policy. It is constructive for the mass media in Nigeria to regularly sensitize the public on the need to manage our waste properly and other environmental issues. The broadcast media for example, can do this by regular news programmes on the environment. There should be discussions, interviews with experts on this issue and phone-in or caller programme to determine public participation and impact. A regular campaign by the media on the environment is essential in environmental management. This is because it helps to shape social norms and values, influence people's decision in manners that promote a more environmentally sustainable society. Attitudinal change or responsible environmental behaviour through self-consciousness of the worth or value of the environment is best approach. 
Citation: Patrick Al, Ferdinard O (2014) Adopting Broadcast Media Sensitization Campaigns for Solid Waste Management. J Mass Communicat Journalism 4: 208. doi:10.4172/2165-7912.1000208

Page 6 of 6

\section{References}

1. Afun S (2009) Government regulations and legislations will ensure sustainable waste Management in Nigeria.

2. Ifegbesan A (2009) Exploring secondary school students' understanding and practices of waste management in Ogun State, Nigeria. International Journa of Environmental Education 5: 201-215.

3. Macawile J, Sia Su G (2009) Local government official's perceptions and attitudes towards solid waste management in Dasmarines, Cavite Philipines. Journal applied science in environment sanitation. 4: 63-69.

4. Kalantari Kh, Asadi A (2010) Designing a structural model for explaining environmental attitude and behavior of urban residents (Case of Tehran). International Journal of Environmental Research 4: 309-320.

5. Banjo AD, Adebambo AARI, Dairo OS (2009) Inhabitants' perception on domestic waste disposal in ljebu Ode, Southwest Nigeria. African Journal of Basic \& Applied Sciences 1: 62-66.
6. Olgyaiová K, Pongrácz E, Mikkola T, Škapa R, Keiski RL (2008) Attitudes toward waste minimization in Finland and Czech Republic-Barriers and drivers. Proceedings of the RESOPT closing seminar 'Waste minimization and utilization in Oulu region: Drivers and constraints', Oulu University Press, Oulu.

7. Rim-Rukeh A, Ogbemi OB (2007) Urban solid waste management: the role of strategic communication. International Journal of Communication 7: 240-246.

8. Rim-Rukeh A, Ogbemi OB (2008) Responsible environmental behaviour: the role of communication. International Journal of Communication 8: 491-501.

9. Barr S (2003) Strategies for sustainability: citizens and responsible environmental behaviour. Area 35: 27-50.

10. Nwabueze C (2007) Environmental communication: perspectives on green communication and information management. Enugu: Daisy Press.

11. Ajayan BA, Saharsh B (2003) Study of the attitude and perception of community waste disposal in ljebu Ode, Southwest Nigeria. African Journal of Basic and Applied Sciences 1: 62-66. 